\title{
Construction of Negative Identity of Female Gender in the Punjabi Proverbs
}

\author{
Saima Mir \\ Department of English Language \& Literature, University of Management \& Technology, Sialkot, Pakistan \\ Email address: \\ saima.mir@skt.umt.edu.pk

\section{To cite this article:} \\ Saima Mir. Construction of Negative Identity of Female Gender in the Punjabi Proverbs. Humanities and Social Sciences. \\ Vol. 6, No. 4, 2018, pp. 125-129. doi: 10.11648/j.hss.20180604.15
}

Received: April 10,2018; Accepted: August 1, 2018; Published: August 16, 2018

\begin{abstract}
Language plays an important role in constructing identities in a society. The Punjabi Language is a member of the modern Indo-Aryan family of languages. It has a very rich culture, especially in the rural areas of Punjab. Punjabi language has a strong connection with the culture and its norms. Punjabi society is a patriarchal society in which, male members who bear the decision-making authority, head the families. Women are usually not included in making decisions and are considered socially and economically dependent on men. Women "consider themselves insecure, incomplete, ineffective and inefficient without males". Therefore, the male dominance becomes one of the significant predictor of the male discrimination against women. Power relations are maintained through the use of Punjabi proverbs. The female gender endures gender discrimination and low self-esteem. Male dominance is also exercised through the use of proverbs. The current research aims to expose the male dominance and the negative connotations attached with the identity of female gender in the Punjabi society. Female gender will get awareness of their identities constructed through the use of language in the proverbs. The qualitative research method has been employed to research randomly selected 20 Punjabi proverbs. It employs critical discourse analysis as its theoretical framework. Norman Fairclough' 3D model has been used to do textual analysis. The proverbs have been taken from the famous book "Punjabi Akhaan". The proverbs have been analyzed on the literal, contextual, syntactic, semantic and pragmatic levels. They have also been dissected on the micro, meso and macro levels to analyze them from the different perspectives. The frequency of the use of Punjabi proverbs has also been observed. After the research, it has been concluded that male dominance in the Punjabi language causes gender discrimination and false representation of female identities. The kind of images constructed in the Punjabi proverbial language truly labels the female gender permanently with the negative connotations. It hinders their progress as well as their status. All the females of Punjabi culture will be benefitted with the current research. It will enable them to understand the kind of male dominance and gender discrimination in the Punjabi language. As a result they will be able to understand the authenticity and the true value attached to these proverbs.
\end{abstract}

Keywords: Power, Dominance, Identity, Language, Proverbs

\section{Introduction}

\subsection{Punjab \& Punjabi Language}

Punjab is Pakistan's second largest province with an area of 205,344 square kilometers (79,284 square mile). It occupies $25.8 \%$ of the total landmass of Pakistan. Punjab borders Jammu and Kashmir in the north, and the Indian states of Punjab and Rajasthan to the east. Punjabi language is written in Shahmukhi alphabet that is very similar to the Urdu alphabet [Wikipedia].

\subsection{Proverbs, Gender and Identity}

Meider [2008] as cited in Rasul [2015] defines proverb as an expression of fundamental truth and is embellished with alliteration and rhyme. They encompass both literal and figurative meaning. It is language that plays a vital role in establishing identity [Dijet, 2000]. The culture of Punjabi society is very rich and the norms and traditions are exhibited in the language of proverbs used mostly by the people of rural areas. A proverb can be considered as a piece of advice concerning a recommended direction of action (although it is not literally a piece of advice). Proverbs are propositions 
loaded with hidden feelings, wishes and intentions of the speaker. They can serve as tools to cover individual opinions in public interactive situations. Like in rhetoric in general the proverbs we use in our speech (and in our inner speech, too) protect our personal attitudes by referring to the third party. They give us persuasiveness by appealing to an authority [Lauhakangas, 2007].

\section{Main Body}

\subsection{Theoretical Framework}

Critical Discourse Analysis is an approach that aims to investigate critically the social inequality. In other words, CDA is concerned with "the study of the relationship between language and the contexts in which it is used" [Van Dijk, 1993]. "It deals primarily with the discourse dimensions of power abuse and the injustice. According to Litosseliti [2000], CDA 'has an explicit interest in making transparent the "hidden agenda" of discourse - which, for instance, may be responsible for creating and sustaining gender inequalities'. Wodak [2002], however, describes it as fundamentally 'interested in not only analyzing opaque but also transparent structural relationships of dominance, discrimination, power and control as manifested in language'. Similarly, Van Dijk [2001] defines CDA as a 'discourse analytical research that primarily studies the way social power abuse, dominance, and inequality are enacted, reproduced, and resisted by text and talk in the social and political context'. The best part of an oral tradition is that even though the speakers are "suspicious of the idea of identity" and "keeping silent about it", yet it speaks it out loudly [Glissant, 2007].

\subsection{Methodology}

The qualitative research method has been employed to research randomly selected 20 Punjabi proverbs. Norman Fairclough' 3D model has been used to do textual analysis.

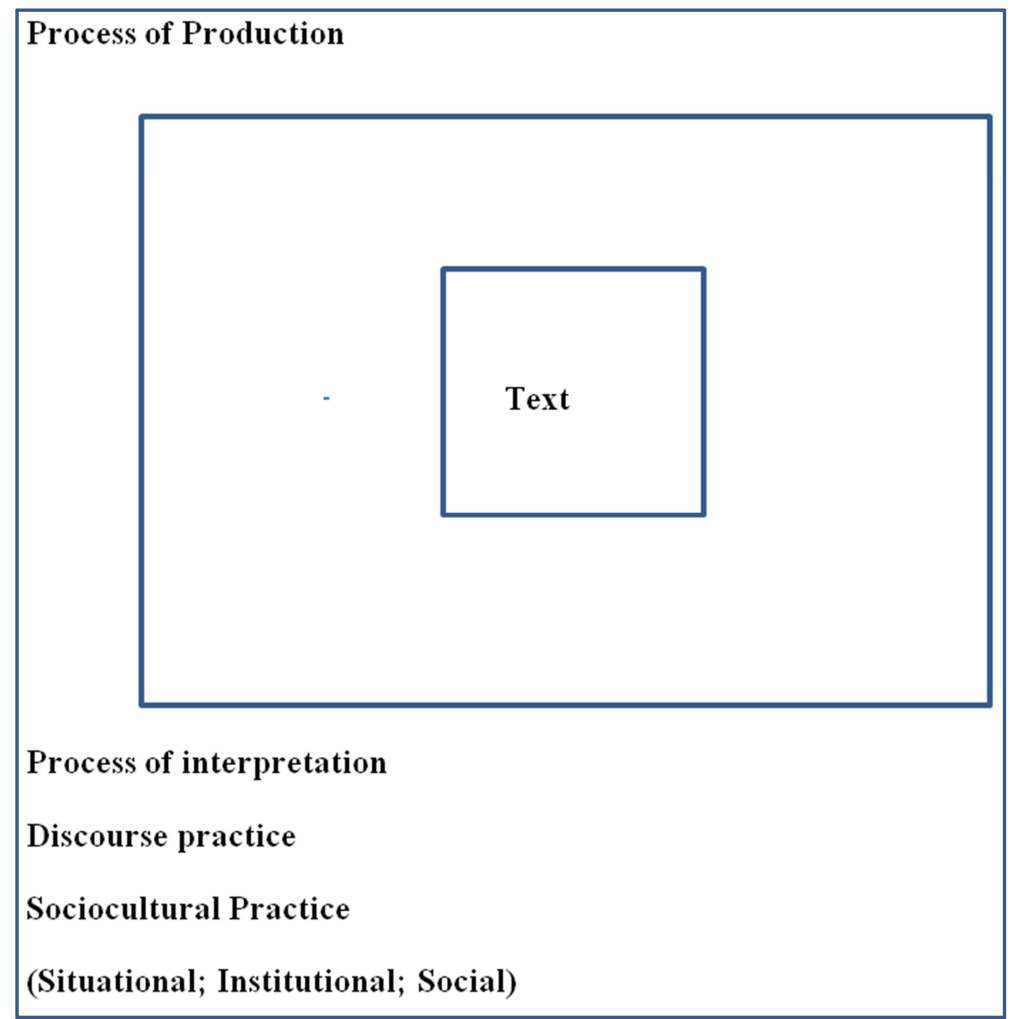

Source: http://www.cscanada.net / index. php /s11/article/view/6401

Figure 1. A Three Dimensional Model of Discourse Analysis.

\section{Data Analyses Tables}

Table 1. Negative Identity of married women constructed as "Runn” having connotations as unfaithful, fashionable, insensible, uncouth and unlucky.

\begin{tabular}{|c|c|c|c|}
\hline & PROVERBS & LITERAL MEANING & CONTEXTUAL MEANING \\
\hline 1. & $\begin{array}{l}\text { Chandri runn daey pujj } \\
\text { sabh injo inj }\end{array}$ & $\begin{array}{l}\text { The unlucky woman has five, all of them are } \\
\text { same. }\end{array}$ & $\begin{array}{l}\text { The bad character of a woman affects the character of her children. It is } \\
\text { all her responsibility. The male gender has been isolated from the } \\
\text { whole scenario. Although, both the genders are responsible for rearing } \\
\text { their children but the mother is always held accountable for the } \\
\text { immoralities of her children. }\end{array}$ \\
\hline
\end{tabular}




\section{PROVERBS}

2. Runn waelli chauselli

Jutti taey runn di ik

3. misaal aey, taey pai nahi taan door hatai

4. Runnan de Zaat baewafa aey

Nikka nikka kam taey ajjarr moi runn

Runnan de khurri picchay mutt

Shaukkan runn taey ghuandh kappata, baey sawad zindagi, phaerra bhata

8. Mard di jutti di wi barkat aey

Shodhay munn bhani tann kanni wi ranni

Buddhi jeundiyyan nitt puarraey

Sunjjay mahal

11 draunaey barkat mardaan naal

Mard matti da whi mann nahi

Dauli kaddan maa

13 paey taey munji kaddan saurey

\section{LITERAL MEANING}

If a woman does not have any work to do, she gets used to staying free and idle.

The example of slippers and married woman is same. The moment it does not fit us we put it away.

The nature of married women is frailty.

She does few chores and is about to die

The brain of married women is at the rear part

The fashionable married woman and the aggressive neighbor spoils the life of their near ones.

The slippers of a man has also got a lot of worth. They are sacred.

If a wife is ugly or blind in one eye or foolish, but if her husband likes her, she is the princess of the house and at the same time she is intelligent too.

If a man marries a woman, then every moment he is in difficulty that woman is a burden on him or marriage is a burden on him.

A castle seems to be a deserted place for a woman if there is no man

If a man is made up of soil, even then, he holds power and prestige

The seat of bride will be taken out by the parents and the deathbed will be taken out by the in- laws
CONTEXTUAL MEANING

The proverb reinforces the stereotypical image of "runn" that connotes wife in the Punjabi culture. The wife should never be let free because she becomes relaxed and sluggish. She has no right to relax as she is born to serve her husband and children.

The proverb metaphorically connotes the real status married women in the society. 'Runn' is a term used for wives. They have been compared with inanimate objects like sleepers. This is done to dominate women and maintain power relations in the text.

The proverb clearly acknowledges and announces that women are always unreliable, unworthy and unfaithful. They can never be trustworthy. This is the negative attribute assigned to women. In order to demean them and making their status low, they are labeled as unfaithful. This proverb is a clear evidence to deteriorate the image of women in the society.

A woman' labor is very tough ie, looking after the house, rearing children, serving her husband and even doing outdoor chores like looking after the animals, doing work in the fields in the Punjabi culture. Despite doing all this work, the kind of identity is constructed that she gets tired of doing little work. The proverb clearly exposes gender discrimination and gender bias.

The married women can never be categorized as thoughtful and wise. This is actually done to dominate the weaker gender and maintain power relations. Women lack the capability to make decisions. They cannot be rational and thoughtful in their dealings. They are actually shown similar to animals, although they are human beings.

'The proverb has used a technique of comparison to expose the idiosyncrasies of wives. The comparison seems to be very illogical. It has been metaphorically suggested that the way an aggressive neighbor spoils one' life, in the same way a fashionable woman spoils her home. A woman has been suggested not to adorn herself. She is born to serve her children, parents and husband. It is considered bad in the society, if a woman devotes a lot of time to her well-being or beauty. This kind of discourse constructs a negative image about fashionable women and differentiate them from other kind of women.

"Mard connotes a very strong, man in the real sense. Mard holds a superior position in the Punjabi culture. The present proverb exposes the superiority of men and their power. The dominance of men has been constructed by elating his very petty outfit ie, jutti' in Punjabi language, which means footwear. The proverb conveys that men are so superior that their footwear is even sacred. This is the height of power relations being constructed between both the genders.

The proverb shows irony in the behavior towards women. The status of men in the Punjabi society is so elated that if he is fascinated by any woman, whether she is blind, she gets the status of a princess. On the other hand, if the woman is perfectly alright, but she is not accepted by a man, she can never be credited as a dignified woman.

The proverb suggests marriage as a sign of misery and burden for a man. The existence of a wife is a burden for him. The women in the lesser position and makes them worthless. The image of wives portrayed in the proverb is offensive and ugly. In reality, wives are the caretakers of their husbands' home and property.

The proverb clearly highlights the superiority and dignified place and position of men in the society as compared to women.

It has been shown that there is no bliss without a man. It has been metaphorically connoted that the castles appear to be deserted if there is no man in it

'Mard' is a connotation used for a typical man in the patriarchal society. 'Matti' is an insignificant thing that is considered to be very petty. The above proverb asserts the importance and superiority of male gender over the female gender. The kind of prestige held by 'mard' in the Punjabi society is unparalleled...

Daughter s are taught in Punjabi custom and tradition that once she is married her dauli (the kind of seat in which she sits as a bride) is taken out by her parents but her death bed will be taken out by her in-laws even though her life becomes miserable. The proverb highlights the cultural belief of the Punjabi society. It is accepted in the society that the parents are responsible for the marriage of the daughter and the 


\begin{tabular}{|c|c|c|c|}
\hline & PROVERBS & LITERAL MEANING & CONTEXTUAL MEANING \\
\hline 14 & $\begin{array}{l}\text { Kattan bhaaj na } \\
\text { saundhiyaan naraan } \\
\text { bhawein lakh hooraan } \\
\text { taey pariyyaan }\end{array}$ & $\begin{array}{l}\text { Wives never appear to be beautiful without } \\
\text { their husbands }\end{array}$ & $\begin{array}{l}\text { death bed is taken out by the in-laws } \\
\text { Even if women are extraordinarily beautiful, then also they only appear } \\
\text { to be desirable along with their husbands. A woman never suits } \\
\text { without her husband. The proverb suggests that a woman does not have } \\
\text { her own identity. Nobody knows where she belongs. She lives her life } \\
\text { at the mercy of her husband. Even, if she possesses all the good } \\
\text { qualities, she is not accepted in the society as a complete being without } \\
\text { her husband }\end{array}$ \\
\hline 15 & $\begin{array}{l}\text { Jaerra runn di mutt } \\
\text { laggay, uh khuaar } \\
\text { thindda aey }\end{array}$ & The man who listens to his wife is shameful. & $\begin{array}{l}\text { The proverb suggests the kind of men who give heed to their wives do } \\
\text { not deserve to be called men. They are shameless. The proverb has } \\
\text { drawn a stereotypical image of such kind of men. It is regarded } \\
\text { unacceptable for men to be obedient and faithful towards their wives in } \\
\text { the society. It also devalues women that they do not hold such worth to } \\
\text { be considered dignified and trustworthy. }\end{array}$ \\
\hline 16 & $\begin{array}{l}\text { Bhuddiyyan winj } \\
\text { karayndean ghaar } \\
\text { buddhay taerra }\end{array}$ & $\begin{array}{l}\text { If a man decides to give the responsibility of } \\
\text { his business dealing to his wife, it } \\
\text { Should be kept in mind that his house will be } \\
\text { destructed. Woman do not have any business } \\
\text { experience. They will get the husband in to } \\
\text { loss. }\end{array}$ & $\begin{array}{l}\text { The women have been suggested as unreliable and untrustworthy. The } \\
\text { men in this proverb have been strictly advised not to share their } \\
\text { business secrets with their wives. The proverb also suggests that a } \\
\text { woman brings destruction to a Man' house. }\end{array}$ \\
\hline 17 & $\begin{array}{l}\text { Aap bibi kokaan } \\
\text { maeinnay deway } \\
\text { lokaan }\end{array}$ & $\begin{array}{l}\text { The person or the woman is immoral, she } \\
\text { always blames other people }\end{array}$ & $\begin{array}{l}\text { The proverb reinforces the bad habits of women. Women always deem } \\
\text { themselves as very pious but taunt others. They find faults with other } \\
\text { people, but always appreciate their own personalities }\end{array}$ \\
\hline 18 & $\begin{array}{l}\text { Teeaan jumdiyyan nu } \\
\text { hai hai }\end{array}$ & $\begin{array}{l}\text { It is a taunt to people of Punjab if woman gives } \\
\text { birth to daughters }\end{array}$ & $\begin{array}{l}\text { The proverb shows that the birth of daughters is a sign of misery. The } \\
\text { society always considers the birth of daughters to be a bad luck for the } \\
\text { parents. Parents of daughters spend their whole life in pain. They are } \\
\text { worried about their own dignity regarding their daughters. }\end{array}$ \\
\hline 19. & $\begin{array}{l}\text { Teeann jamdiyyan } \\
\text { naey taey maa paey } \\
\text { neuw jandein naey }\end{array}$ & $\begin{array}{l}\text { Parents of daughters always bend down when } \\
\text { their daughters are born because in future they } \\
\text { don't know how the in-laws how the husbands } \\
\text { will behave with them so they try to see them } \\
\text { happy. }\end{array}$ & $\begin{array}{l}\text { The proverb highlights the negative attitude and immature thought } \\
\text { content of the society towards daughters. It is expressed that parents of } \\
\text { daughters cannot survive with honor and dignity. They always have to } \\
\text { bow down in front of others and take others' dictation. It is reinforced } \\
\text { that the birth of daughters make their parents low in stature. }\end{array}$ \\
\hline 20. & $\begin{array}{l}\text { Runnan naal matha } \\
\text { laway, Taan kannan di } \\
\text { khair mananwaey }\end{array}$ & $\begin{array}{l}\text { Those who fight with women, wives or widow, } \\
\text { they should take care of their ears. }\end{array}$ & $\begin{array}{l}\text { The present proverb reinforces the stereotypical image of women as } \\
\text { very talkative. It has been forbidden in the negative sense to argue with } \\
\text { women, otherwise the person who does will be held responsible for the } \\
\text { pain endured. }\end{array}$ \\
\hline
\end{tabular}

\section{Discussion}

Wardhaugh (2002) asserts that gender to be male or female is socially constructed. The use of such discourse in the above proverbs reinforces the dominance of the powerful gender. Negation in the proverbial text has been used to show that a woman can never take the position of a man. It is used to distance women from men and put them in the lower position. The proverb suggests men as the chief authority of the society. Power of men has been shown by the usage of negation in the proverb. It has also been constructed to silence the women of the society. Moreover, it is suggested that no matter what happens to her, she has to bear the ruthless behavior of her in-laws and only gets relief when she dies. In the Punjabi culture, if a woman wants to live alone, she cannot do that. She has been shown to be dependent for the whole of his life. This also exposes the gender bias between the same genders.

Women have been shown silly and foolish. On one hand, they are the life partners, mothers and daughters, who sacrifice their wishes for the sake of the welfare of their families. But on the other hand, it is ingrained in the minds of men not to rely on women. There is sense of insecurity for the female gender that prevails in such ideologies. In the
Punjabi culture, daughters are considered to be a symbol of prestige for them. If they commit any immoral act, the parents get to the deathbed or they kill themselves with their own hands. So, there is a lot of pressure from the society for the parents of the daughters.

The construction of ideologies in the above- mentioned proverbs make women less confident and aggressive. Power is asserted by creating such stereotypes to make them more submissive. The analysis also draws the attention to the fact that whosoever is actually responsible for determining a woman to be good or bad. It is an equal right of a woman to adore and groom herself. Religion, itself has permitted women to adorn them within the spheres of Islam. They have their own likes and dislikes which should not be discouraged. In reality, women are empowering themselves to the height of getting excellence in every field of life. But their status is lowered to such extent that they are unable to get dignity from the dominant group.

The proverbs actually assert the male power and gender inequality in the Punjabi society. It puts the lives of women at risk. This kind of image of women in the proverb affects their well-being and overall image. The society is never ready to give any dignity and worth to it. The positive nature of men has been stigmatized in order to divert them from their natural behavior. It is observed that they are forced by their 
dominant group not to violate the set norms of the society. The ideology constructed in the proverb affects the social system of the society.

Negative image of wives has been portrayed to show that they are unettiquetted and uncivilized. They do not know how to have conversation and argument with other people. This has been done to demean and belittle women.

Negation like "na" can be manipulative, ideological and insincere. The language in the above proverbs also highlight the gender bias against women and asserts superiority of men. Negation is a technique through which, power imbalance can be illustrated in the proverbs. Fairclough (1989) claims that negation differentiates the real from the unreal. Males also use their social power for the manipulating of the minds of females for their own interests. "This is a crucial point where discourse and CDA comes in: managing the minds of others is essentially a function of text and talk" [Fairclough, 1985].

\section{Conclusion}

The main aim of the researcher in the current research was to explore the hidden constructions of power relations by the male gender and female stereotyping. This has been researched with the help of probing Punjabi history, culture, literature and the status of both the genders in the rural settings of Punjabi society of the suburbs of Sialkot. The researcher hopes to have supported his claims by the findings of the analysis and the subsequent tables. The researcher hopes to have achieved the objectives of the current study. According to Bruyn and France (2001), societies in various corners of the world marginalize females by totally vesting economic and political power to masculinity. According to Lukes [1986] as [cited in Van Dijk, 1993] "such inferior and dehumanized image of females provide males the social power of controlling all the resources, such as force, money, status, fame, knowledge, information, and culture". As a result, males get social power base to limit the freedom of their female counterparts and influence their minds, too. Besides, males also use this social power for the manipulating of the minds of females for their own interests (Fairclough, 1985), which has been clearly reflected in the overall analysis of proverbs in Punjabi society.

\section{References}

[1] Bruyn, D. M., \& France, N. (2001). Gender or sex: Who cares? Skills-building resource pack on gender and reproductive health for adolescents and youth workers with a special emphasis on violence, HIV/STIs, unwanted pregnancy and unsafe abortion. USA: Americolor, Garner, NC.

[2] Dwivedi, A. V. (2015). Proverbs and Identity: A Study of Hadoti Proverbs. Entrepalavras, 5 (1), 8- 19.

[3] Fairclough, N. L. (1985). Critical and descriptive goals in discourse analysis. Journal of Pragmatics, 9, 739-63.

[4] Glissant, E. Memoires des esclavages. Paris: Gallimard, 2007.

[5] https://en.wikipedia.org/wiki/Punjab,_Pakistan.

[6] Khan, Q., Sultana, N., \& Naz, A. (2015). The linguistic representation of gender identities in Pakhtu proverbs. NUML Journal of Critical Inquiry, 13 (2), 73.

[7] Lukes, S. (Ed.). (1986). Power. Oxford: Blackwell.

[8] Lauhakangas, O. (2007). Use of proverbs and narrative thought. Folklore, 35, 77-84.

[9] Mieder, W. Definition and Classification. In. Proverbs: a handbook. London: Greenwood Press, 2004.

[10] Mubarok, Y. [2017], Representation of Women in the Sundanese Proverbs. 4th International Conference on Education and Social Sciences. 6-8 February 2017-Istanbul, Turkey.

[11] Rasul, S. (2015). Gender and Power Relationships in the Language of Proverbs: Image of a Woman. FWU Journal of Social Sciences, 9 (2), 53. 